\title{
Evaluation of some of the Metal Levels at Different Depths from Gulf of Guinea Offshore Location
}

\author{
${ }^{1}$ JOEL, O. F.; ${ }^{2}$ AKINDE, S. B. \\ ${ }^{I}$ Department of Petroleum and Gas Engineering, Faculty of Engineering, University of Port Harcourt, Nigeria. E- \\ mail:Ogbonna.Joel@yahoo.com; 2348037099211/2348052276568 \\ ${ }^{2}$ Department of Applied and Environmental Biology, Rivers State University of Science and Technology, Port Harcourt, Nigeria. E-mail: \\ tundeakinde@yahoo.com: 2348033798688
}

\begin{abstract}
Study area is in the Nigeria continental shelf of the Atlantic Ocean, located within seawater depths of $20-25 \mathrm{~m}$ and geographic X and Y coordinates 337896 - 356905 and 469773 - 482786, offshore Nigeria respectively. Test was conducted to evaluate some of the metal levels at different depths from Gulf of Guinea offshore location. Samples were collected from the depth of $5 \mathrm{~m}, 10 \mathrm{~m}, 15 \mathrm{~m}$ and $20 \mathrm{~m}$ respectively and tests were conducted over a one year period on a quarterly basis. Test result indicated that mean value over the period for the metals tested was: $\mathrm{Mg}(1160 \mathrm{mg} / \mathrm{l}), \mathrm{K}(369 \mathrm{mg} / \mathrm{l}), \mathrm{Na}(8062 \mathrm{mg} / \mathrm{l}), \mathrm{Ca}(380 \mathrm{mg} / \mathrm{l}), \mathrm{Al}(<1.0 \mathrm{mg} / \mathrm{l}), \mathrm{Fe}(0.05 \mathrm{mg} / \mathrm{l})$, $\mathrm{Cu}(<0.05 \mathrm{mg} / 1), \mathrm{Mn}(<0.10 \mathrm{mg} / 1), \mathrm{Zn}(<0.05 \mathrm{mg} / \mathrm{l}), \mathrm{Ba}(<0.03 \mathrm{mg} / \mathrm{l}), \mathrm{Si}(<0.01 \mathrm{mg} / 1), \mathrm{Sr}(0.569 \mathrm{mg} / 1), \mathrm{Li}(0.559 \mathrm{mg} / 1)$. This project therefore will help to provide a base-line data on the metal constituents of the Gulf of Guinea offshore location, thereby helping framework for environmental protection for offshore oil and gas activities in the Gulf of Guinea@JASEM
\end{abstract}

The Gulf of Guinea is located on the west central coast of Africa and encompasses the countries of Nigeria, Chad, Cameroon, Equatorial Guinea, Angola, Sao Tome and Principe, Gabon and Congo. From a marine ecology perspective, the region is also known as the Guinea Current Large Marine Ecosystem and encompasses all the coastal countries from Guinea Bissau in the North to Angola in the South (Moreno, 2009). The Gulf of Guinea is the part of the Atlantic Ocean southwest of Africa. The intersection of the Equator and Prime Meridian (zero degrees latitude and longitude) is in the gulf (www.en.wikipedia.org; Oct, $4^{\text {th }}, 2009$ ). About $40 \%$ of the people in the region live in coastal area. The Gulf of Guinea has estimated reserves of 24 billion barrels of oil. Estimates indicate that the Gulf of Guinea countries already account for $4.2 \%$ of world oil reserves and $6.5 \%$ of oil production in 2007. However, this number is expected to grow, given that exploration is only now commencing in some offshore areas. For years, Nigeria has been a major exporter of oil, with Angola now joining the ranks of the major producers. In regards to the U.S., West and Central African countries provide $12-15 \%$ of its oil supply. That number is expected to grow to almost $25 \%$ by 2020 . China has also shown increasing interest in the region and now counts Angola as its top oil supplier(Moreno, 2009).A significant amount of the region's growth in oil production will be from offshore lease blocks. Some countries like Nigeria and Angola are already producing from offshore areas in the Gulf of Guinea, while others are starting to conduct exploration activities. By some estimates, West Africa already has up to 547 major offshore oil and gas structures. In addition to the economic and governmental challenges that an oil boom brings to a developing country, there are also environmental risks that must be addressed. Regions made up of developing countries often do not have the resources and governmental structures required to create and manage a legal framework for the prevention of environmental harm from offshore oil and gas exploration and production (E \& $\mathrm{P}$ ) activities (Moreno, 2009)

Offshore E \& P offers significant benefits over onshore oil production. For example, it minimizes the possibility of disruptions caused by violence and war. It also provides the possibility of shipping oil directly to the major consumers (e.g. the U.S.) without having to bring the oil onshore to potentially volatile areas. Currently, offshore production accounts for up to $30 \%$ of the world's oil and gas production. That percentage is expected to rise in the future.

However, offshore E \& $\mathrm{P}$ activities are not without disadvantages. Offshore development, especially deepwater development, requires a significant technological investment. In addition, offshore oil development brings some inherent environmental challenges. It can be a significant threat to the marine environment and ecosystem. Similar to onshore development, it creates atmospheric emissions. Finally, after the oil has dried up, there is the significant challenge of what to do with abandoned platforms, i.e. decommissioning. In areas with significant resources such as the Gulf of Mexico or the North Sea, extensive regulator frameworks have been required to mitigate these potential damages. However, offshore development in developing countries may result in unmitigated environmental risks. Such environmental protection associated with offshore development may be only an afterthought, if

* Corresponding author: Joel, O. F. 
nothing is done proactively, it may later be too late to reverse the environmental harm. It is not uncommon for steams or water bodies to be almost or completely anaerobic and heavily polluted with organic compounds, pathogens, and heavy metals (World Bank, 1993).

The objective of this project therefore is to determine the levels of some metal ions in the Gulf of Guinea offshore location with a view to provide a base-line data to enable Government develop a framework for environmental protection for offshore oil and gas activities in the Gulf of Guinea.

\section{MATERIALS AND METHODS}

Sample Collection and Preparation: Seawater samples in the study area were collected using a SeaBird Electronics (SBE) 32 Carousel water sampler and the Sea-cat water profiler. Carousel is a specialized equipment comprising twelve (12) water sampling bottles (8litres size) and an automatic fire module (model AFM $6800 \mathrm{~m}$ ). Six (6) out of the twelve bottles were used for sampling. The AFM is programmed to trigger the bottles for sample collection at desired depths using a special computer programme (SeaTermAF Version 1.1.3). A Sea-cat Water Profiler (SWP) with CTD model SBE 19 plus $7000 \mathrm{~m}$ attached to the carousel was used to carry out in situ measurement of seawater. On completion of profiling data uploading from the SWP at each station, the generated data was erased from the instrument's internal memory to avoid mix up during subsequent profiling. The instrument was thus prepared for next deployment. The seawater samples collected at each station were preserved accordingly.

Sampling protocols in line with analytical procedures as outlined in Part VII Section D of Guidelines and Standards for the Petroleum Industry were followed (DPR, 1991; DPR, 2002; FEPA, 1991). All the collected samples were preserved in accordance with guidelines and International Standards. All other QA/QC procedures relevant to sample collection, custody and analyses were strictly adhered to (APHA, 1985, APHA, 1995; ASTM, 1979).

Metals Determination: Samples were pre-treated with $2 \mathrm{ml}$ conc. $\mathrm{HNO}_{3}$ per litre of sample. A measured quantity of the samples were transferred into a Kjeldahl flask; $20 \mathrm{ml}$ of concentrated nitric acid $\left(\mathrm{HNO}_{3}\right)$ was added and the sample pre-digested by heating gently for $20 \mathrm{mins}$. More acid was thereafter added and digestion was continued for 30-40mins. Digestion was stopped when a clear digest was obtained. The flask was cooled and the content transferred into a $50 \mathrm{ml}$ volumetric flask and made to the mark with distilled water. The following wavelengths used for each metal include: $(\mathrm{Mg}=285.2 \mathrm{~nm}, \quad \mathrm{~K}=766.5 \mathrm{~nm}, \quad \mathrm{Na}=589 \mathrm{~nm}$, $\mathrm{Ca}=422.7 \mathrm{~nm}, \quad \mathrm{Al}=309.3 \mathrm{~nm}, \quad \mathrm{Fe}=248.3 \mathrm{~nm}$, $\mathrm{Cu}=324.7 \mathrm{~nm}, \quad \mathrm{Mn}=279.5 \mathrm{~nm}, \quad \mathrm{Zn}=213.9 \mathrm{~nm}$, $\mathrm{Ba}=553.6 \mathrm{~nm}, \quad \mathrm{Si}=251.6 \mathrm{~nm}, \quad \mathrm{Sr}=460.7 \mathrm{~nm}$, $\mathrm{Li}=670.8 \mathrm{~nm})$. The metals were determined using the 205 BUCK SCIENTIFIC MODEL, AAS.

\section{RESULTS AND DISCUSSION}

Table-1: Metal Parameters of $1^{\text {st }}$ Quarter

\begin{tabular}{|c|c|c|c|c|c|c|c|c|c|c|c|c|c|}
\hline Parameters & $\begin{array}{l}\mathrm{Mg} \\
(\mathrm{mg} / \mathrm{l})\end{array}$ & $\begin{array}{l}\mathrm{K} \\
(\mathrm{mg} / \mathrm{l})\end{array}$ & $\begin{array}{l}\mathrm{Na} \\
(\mathrm{mg} / \mathrm{l})\end{array}$ & $\begin{array}{l}\mathrm{Ca} \\
(\mathrm{mg} / \mathrm{l})\end{array}$ & $\begin{array}{l}\mathrm{Al} \\
(\mathrm{mg})\end{array}$ & $\begin{array}{l}\mathrm{Fe} \\
(\mathrm{mg} / \mathrm{l})\end{array}$ & $\begin{array}{l}\mathrm{Cu} \\
(\mathrm{mg} / \mathrm{l})\end{array}$ & $\begin{array}{l}\mathrm{Mn} \\
(\mathrm{mg} / \mathrm{l})\end{array}$ & $\begin{array}{l}\mathrm{Zn} \\
(\mathrm{mg} / \mathrm{l})\end{array}$ & $\begin{array}{l}\mathrm{Ba} \\
(\mathrm{mg} / \mathrm{l})\end{array}$ & $\begin{array}{l}\mathrm{Si} \\
(\mathrm{mg} / \mathrm{l})\end{array}$ & $\begin{array}{l}\mathrm{Sr} \\
(\mathrm{mg} / \mathrm{l})\end{array}$ & $\begin{array}{l}\mathrm{Li} \\
(\mathrm{mg} / \mathrm{l})\end{array}$ \\
\hline \multicolumn{14}{|l|}{ Depths } \\
\hline $5 \mathrm{~m}$ & 1111 & 346 & 9120 & 357 & $<1.0$ & $<0.05$ & $<0.05$ & $<0.10$ & $<0.05$ & $<0.03$ & 0.01 & 0.41 & 0.07 \\
\hline $10 \mathrm{~m}$ & 1115 & 347 & 9150 & 359 & $<1.0$ & $<0.05$ & $<0.05$ & $<0.10$ & $<0.05$ & $<0.03$ & $<0.01$ & 0.43 & 0.09 \\
\hline $15 \mathrm{~m}$ & 1141 & 353 & 9360 & 367 & $<1.0$ & $<0.05$ & $<0.05$ & $<0.10$ & $<0.05$ & $<0.03$ & $<0.01$ & 0.43 & 0.13 \\
\hline $20 \mathrm{~m}$ & 1159 & 362 & 9510 & 373 & $<1.0$ & $<0.05$ & $<0.05$ & $<0.10$ & $<0.05$ & $<0.03$ & $<0.01$ & 0.44 & 0.14 \\
\hline Mean & 1132 & 352 & 9285 & 364 & $<1.0$ & $<0.05$ & $<0.1$ & $<0.05$ & $<0.03$ & $<0.01$ & $<0.01$ & 0.428 & 0.108 \\
\hline
\end{tabular}

Table-2: Metal Parameters of $2^{\text {nd }}$ Quarter

\begin{tabular}{|c|c|c|c|c|c|c|c|c|c|c|c|c|c|}
\hline Parameters & $\begin{array}{l}\mathrm{Mg} \\
(\mathrm{mg} / \mathrm{l})\end{array}$ & $\begin{array}{l}\mathrm{K} \\
(\mathrm{mg} / \mathrm{l})\end{array}$ & $\begin{array}{l}\mathrm{Na} \\
(\mathrm{mg} / \mathrm{l})\end{array}$ & $\begin{array}{l}\mathrm{Ca} \\
(\mathrm{mg} / 1)\end{array}$ & $\begin{array}{l}\mathrm{Al} \\
(\mathrm{mg} / \mathrm{l})\end{array}$ & $\begin{array}{l}\mathrm{Fe} \\
(\mathrm{mg} / \mathrm{l})\end{array}$ & $\begin{array}{l}\mathrm{Cu} \\
(\mathrm{mg} / 1)\end{array}$ & $\begin{array}{l}\mathrm{Mn} \\
(\mathrm{mg} / \mathrm{l})\end{array}$ & $\begin{array}{l}\mathrm{Zn} \\
(\mathrm{mg} / \mathrm{l})\end{array}$ & $\begin{array}{l}\mathrm{Ba} \\
(\mathrm{mg} / 1)\end{array}$ & $\begin{array}{l}\mathrm{Si} \\
(\mathrm{mg} / \mathrm{l})\end{array}$ & $\begin{array}{l}\mathrm{Sr} \\
(\mathrm{mg} / \mathrm{l})\end{array}$ & $\begin{array}{l}\mathrm{Li} \\
(\mathrm{mg} / \mathrm{l})\end{array}$ \\
\hline \multicolumn{14}{|l|}{ Depths } \\
\hline $5 \mathrm{~m}$ & 1240 & 378 & 10150 & 384 & $<1.0$ & $<0.05$ & $<0.05$ & $<0.10$ & $<0.05$ & $<0.03$ & $<0.01$ & 0.44 & 0.83 \\
\hline $10 \mathrm{~m}$ & 1214 & 369 & 9900 & 390 & $<1.0$ & $<0.05$ & $<0.05$ & $<0.10$ & $<0.05$ & $<0.03$ & $<0.01$ & 0.42 & 0.84 \\
\hline $15 \mathrm{~m}$ & 1265 & 369 & 10420 & 401 & $<1.0$ & $<0.05$ & $<0.05$ & $<0.10$ & $<0.05$ & $<0.03$ & $<0.01$ & 0.44 & 0.80 \\
\hline $20 \mathrm{~m}$ & 1273 & 399 & 10480 & 400 & $<1.0$ & $<0.05$ & $<0.05$ & $<0.10$ & $<0.05$ & $<0.03$ & $<0.01$ & 0.37 & 0.84 \\
\hline Mean & 1248 & 379 & 10238 & 394 & $<1.0$ & $<0.05$ & $<0.05$ & $<0.10$ & $<0.05$ & $<0.03$ & $<0.01$ & 0.418 & 0.828 \\
\hline
\end{tabular}

\footnotetext{
* Corresponding author: Joel, O. F.
} 
Table-3: Metal Parameters of $3^{\text {rd }}$ Quarter

\begin{tabular}{|c|c|c|c|c|c|c|c|c|c|c|c|c|c|}
\hline Parameters & $\begin{array}{l}\mathrm{Mg} \\
(\mathrm{mg} / \mathrm{l})\end{array}$ & $\begin{array}{l}\mathrm{K} \\
(\mathrm{mg} / \mathrm{l})\end{array}$ & $\begin{array}{l}\mathrm{Na} \\
(\mathrm{mg} / \mathrm{l})\end{array}$ & $\begin{array}{l}\mathrm{Ca} \\
(\mathrm{mg} / \mathrm{l})\end{array}$ & $\begin{array}{l}\mathrm{Al} \\
(\mathrm{mg} / \mathrm{l})\end{array}$ & $\begin{array}{l}\mathrm{Fe} \\
(\mathrm{mg} / \mathrm{l})\end{array}$ & $\begin{array}{l}\mathrm{Cu} \\
(\mathrm{mg} / \mathrm{l})\end{array}$ & $\begin{array}{l}\mathrm{Mn} \\
(\mathrm{mg} / \mathrm{l})\end{array}$ & $\begin{array}{l}\mathrm{Zn} \\
(\mathrm{mg} / \mathrm{l})\end{array}$ & $\begin{array}{l}\mathrm{Ba} \\
(\mathrm{mg} / \mathrm{l})\end{array}$ & $\begin{array}{l}\mathrm{Si} \\
(\mathrm{mg} / \mathrm{l})\end{array}$ & $\begin{array}{l}\mathrm{Sr} \\
(\mathrm{mg} / \mathrm{l})\end{array}$ & $\begin{array}{l}\mathrm{Li} \\
(\mathrm{mg} / \mathrm{l}) \\
\end{array}$ \\
\hline $5 \mathrm{~m}$ & 1042 & 348 & 8504 & 381 & $<1.0$ & $<0.05$ & $<0.05$ & $<0.10$ & $<0.05$ & $<0.03$ & $<0.01$ & 0.87 & 0.62 \\
\hline $15 \mathrm{~m}$ & 1060 & 383 & 8737 & 398 & $<1.0$ & $<0.05$ & $<0.05$ & $<0.10$ & $<0.05$ & $<0.03$ & $<0.01$ & 0.93 & 0.58 \\
\hline $20 \mathrm{~m}$ & 1075 & 405 & 9996 & 401 & $<1.0$ & $<0.05$ & $<0.05$ & $<0.10$ & $<0.05$ & $<0.03$ & $<0.01$ & 0.97 & 0.64 \\
\hline
\end{tabular}

Table-4: Metal Parameters of $4^{\text {th }}$ Quarter

\begin{tabular}{|c|c|c|c|c|c|c|c|c|c|c|c|c|c|}
\hline Parameters & $\begin{array}{l}\mathrm{Mg} \\
(\mathrm{mg} / \mathrm{l})\end{array}$ & $\begin{array}{l}\mathrm{K} \\
(\mathrm{mg} / \mathrm{l})\end{array}$ & $\begin{array}{l}\mathrm{Na} \\
(\mathrm{mg} / \mathrm{l})\end{array}$ & $\begin{array}{l}\mathrm{Ca} \\
(\mathrm{mg} / \mathrm{l})\end{array}$ & $\begin{array}{l}\mathrm{Al} \\
(\mathrm{mg} / \mathrm{l})\end{array}$ & $\begin{array}{l}\mathrm{Fe} \\
(\mathrm{mg} / \mathrm{l})\end{array}$ & $\begin{array}{l}\mathrm{Cu} \\
(\mathrm{mg} / \mathrm{l})\end{array}$ & $\begin{array}{l}\mathrm{Mn} \\
(\mathrm{mg} / \mathrm{l})\end{array}$ & $\begin{array}{l}\mathrm{Zn} \\
(\mathrm{mg} / \mathrm{l})\end{array}$ & $\begin{array}{l}\mathrm{Ba} \\
(\mathrm{mg} / \mathrm{l})\end{array}$ & $\begin{array}{l}\mathrm{Si} \\
(\mathrm{mg} / \mathrm{l})\end{array}$ & $\begin{array}{l}\mathrm{Sr} \\
(\mathrm{mg} / \mathrm{l})\end{array}$ & $\begin{array}{l}\mathrm{Li} \\
(\mathrm{mg} / \mathrm{l}) \\
\end{array}$ \\
\hline $5 \mathrm{~m}$ & 947 & 285 & 2994 & 363 & $<1.0$ & $<0.05$ & $<0.05$ & $<0.10$ & $<0.05$ & $<0.03$ & $<0.01$ & 0.41 & 0.30 \\
\hline $15 \mathrm{~m}$ & 1263 & 371 & 4446 & 375 & $<1.0$ & $<0.05$ & $<0.05$ & $<0.10$ & $<0.05$ & $<0.03$ & $<0.01$ & 0.56 & 0.40 \\
\hline $20 \mathrm{~m}$ & 1326 & 371 & 4190 & 384 & $<1.0$ & $<0.05$ & $<0.05$ & $<0.10$ & $<0.05$ & $<0.03$ & $<0.01$ & 0.56 & 0.40 \\
\hline
\end{tabular}

Table 5: Quarterly Mean Values and Standard Deviation Analysis

\begin{tabular}{|c|c|c|c|c|c|c|c|c|c|c|c|c|c|}
\hline Parameters & $\begin{array}{l}\mathrm{Mg} \\
(\mathrm{mg} / \mathrm{l})\end{array}$ & $\begin{array}{l}\mathrm{K} \\
(\mathrm{mg} / \mathrm{l})\end{array}$ & $\begin{array}{l}\mathrm{Na} \\
(\mathrm{mg} / \mathrm{l})\end{array}$ & $\begin{array}{l}\mathrm{Ca} \\
(\mathrm{mg} / \mathrm{l})\end{array}$ & $\begin{array}{l}\mathrm{Al} \\
(\mathrm{mg} / \mathrm{l})\end{array}$ & $\begin{array}{l}\mathrm{Fe} \\
(\mathrm{mg} / \mathrm{l})\end{array}$ & $\begin{array}{l}\mathrm{Cu} \\
(\mathrm{mg} / \mathrm{l})\end{array}$ & $\begin{array}{l}\mathrm{Mn} \\
(\mathrm{mg} / \mathrm{l})\end{array}$ & $\begin{array}{l}\mathrm{Zn} \\
(\mathrm{mg} / \mathrm{l})\end{array}$ & $\begin{array}{l}\mathrm{Ba} \\
(\mathrm{mg} / \mathrm{l})\end{array}$ & $\begin{array}{l}\mathrm{Si} \\
(\mathrm{mg} / \mathrm{l})\end{array}$ & $\begin{array}{l}\mathrm{Sr} \\
(\mathrm{mg} / \mathrm{l})\end{array}$ & $\begin{array}{l}\mathrm{Li} \\
(\mathrm{mg} / \mathrm{l})\end{array}$ \\
\hline $1^{\mathrm{st}}$ & 1132 & 352 & 9285 & 364 & $<1.0$ & $<0.05$ & $<0.05$ & $<0.10$ & $<0.05$ & $<0.03$ & $<0.01$ & 0.428 & 0.108 \\
\hline $3^{\text {rd }}$ & 1058 & 371 & 8851 & 391 & $<1.0$ & $<0.05$ & $<0.05$ & $<0.10$ & $<0.05$ & $<0.03$ & $<0.01$ & 0.918 & 0.618 \\
\hline $4^{\text {th }}$ & 1202 & 374 & 3875 & 372 & $<1.0$ & $<0.05$ & $<0.05$ & $<0.10$ & $<0.05$ & $<0.03$ & $<0.01$ & 0.513 & 0.360 \\
\hline Mean & 1160 & 369 & 8062 & 380 & $<1.0$ & $<0.05$ & $<0.05$ & $<0.10$ & $<0.05$ & $<0.03$ & $<0.01$ & 0.569 & 0.479 \\
\hline
\end{tabular}

Table (1-4) present results of the tests conducted for the various metal concentrations for the four quarters and at the different depths as applicable. Table-1 shows results for metals evaluated for the $1^{\text {st }}$ quarter, table-2 for $2^{\text {nd }}$ quarter, table- 3 for $3^{\text {rd }}$ quarter and table- 4 for the $4^{\text {th }}$ quarter for $5 \mathrm{~m}, 10 \mathrm{~m}, 15 \mathrm{~m}$ and $20 \mathrm{~m}$ respectively. A closer look on the distribution of the mean values during the different quarters at the different depths (table 2-4) indicated that some of the metals had slightly higher values with increase in depth. As shown in table-5, Magnesium had highest mean value of $1248 \mathrm{mg} / 1$ at the $2^{\text {nd }}$ quarter and lowest mean value of $1058 \mathrm{mg} / 1$ during the $3^{\text {rd }}$ quarter. Potassium had the highest mean value of $378 \mathrm{mg} / 1$ during the $2^{\text {nd }}$ quarter and lowest mean value of $352 \mathrm{mg} / 1$ at the $1^{\text {st }}$ quarter. Sodium had highest mean value of $10,238 \mathrm{mg} / 1$ at the $2^{\text {nd }}$ quarter and lowest mean value of $3875 \mathrm{mg} / 1$ at the $4^{\text {th }}$ quarter. Calcium had the highest mean value of $394 \mathrm{mg} / 1$ during the $2^{\text {nd }}$ quarter and lowest mean value of $364 \mathrm{mg} / \mathrm{l}$ during the $1^{\text {st }}$ quarter.

The values for Aluminum, Iron, Copper, Manganese, Zinc, Barium, and Silicon were the same in all the depths tested in all the quarters (table1-5). However,
Magnesium, Potassium, Sodium, Calcium, and Lithium gave values which showed an increase with increase in depth. This could be attributed to settling tendencies due to gravitational effect and sedimentation.

As could be seen in the result of the standard deviation (table-5), the higher the standard deviation value, the higher the variance in the metal concentrations during the periods and the respective depths. The metals that the concentrations were the same all through the period and in all the depths had zero standard deviation. The higher concentrations of the chloride ions as seen in the test results is an indication of high salinity of the water, affirming that the water is salty, typical of offshore locations.

Conclusion: Results of constituents of the heavy metals as determined will provide a base-line data of the Gulf of Guinea offshore location. This will help develop a blue print for environmental protection on offshore oil and gas activities in the Gulf of Guinea. Unlike the Gulf of Mexico and the North Sea, where prudent care and adequate protection for the environment is the norm, this region, Gulf of Guinea 
currently lacks a comprehensive environmental protection plan to address offshore oil and gas exploration and production, therefore, it is imperative that Government should take a proactive step and come up with extensive regulatory frame work to mitigate the potential damage that could arise from the exploration and production activities in the Gulf of Guinea.

\section{REFERENCES}

APHA (1985). Standard Methods for the examination of Water and Wastewater. American Public Health Association, 15 Ed, Pg128.

APHA (1995). Standard Methods for the Examination of Water/ Waste water. APHAAWWA-WPCF, Washington D. C. 20036.

ASTM (1979). Annual Book of America Society for Testing and Materials Standards, 1527, Philadelphia.

ASTM, (1995). Ed. Water and Environmental Technology, American Standard Testing Method, 1995 Vols. 1 \& 2.

DPR (1991). Department of Petroleum Resources, 1991, Environmental Guidelines and Standards for the Petroleum Industry in Nigeria. Production and Terminal Operations. Department of Petroleum Resources, Ministry of Petroleum Resources, Lagos.

FEPA (1995). Federal Environmental Protection Agency, 1995. Corporate Profile, Garki, FCT, Abuja, Nigeria.

DPR, (2002). Environmental Guidelines and Standards for the Petroleum Industry in Nigeria (EGASPIN), Revised Edition 2002.

Moreno, CJ (2009), Oil and Gas exploration and production in the Gulf of Guinea: Can the new Gulf be Green? Houston Journal of International Law, Spring 2009.

Moreno, CJ (2009), "Oil and Gas in the Gulf of Guinea”, Houston J. Inter. Law, Spring 2009.

Moreno, CJ (2009), “Offshore E\&P and its Environmental impacts”, Houston J. Inter. Law, Spring 2009.

World Bank, (1993). Water Resources Management. World Bank Policy Paper. Washington, DC.

www.en.wikipedia.org/wiki/Gulf_of_Guinea, October, $4^{\text {th }}, 2009$.

* Corresponding author: Joel, O. F. 